\title{
EVALUASI PELAKSANAAN TUGAS DAN FUNGSI KANTOR PELAYANAN PAJAK DALAM PENGOLAHAN SURAT
}

\author{
Agus Bandiyono dan Dinda Rahmawati \\ Politeknik Keuangan Negara STAN Jakarta
}

\begin{abstract}
Evaluation of Duties and Functions of Tax Service Offices in Letter Processing. This study aims to evaluate the implementation of the duties and functions of the Primary KPP in receiving and processing notification letters; and knowing the obstacles to the implementation of duties and functions of the Pondok Aren Primary KPP in receiving and processing notification letters. The method used is the Literature Study Method, Field Study Methods through interviews, observation and questionnaires. The result is that in general Pondok Aren Primary KPP has carried out its duties and functions in receiving and processing notification letters well. This can be seen from several indicators conveyed by Cambell as material for evaluating the implementation of duties and functions of Pondok Aren Primary KPP in receiving and processing notification letters. One of them is organizational effectiveness which can be seen from NKO KPP Pratama Pondok Aren and IKU employees as well as IKU Pratama KPP Pondok Aren as a whole. The author uses the target Organizational Performance Value as an evaluation of the implementation of duties and functions of the Pondok Aren Primary KPP in receiving and processing notification letters.
\end{abstract}

\begin{abstract}
Abstrak: Evaluasi Pelaksanaan Tugas dan Fungsi Kantor Pelayanan Pajak dalam Pengolahan Surat. Penelitian ini bertujuan untuk mengevaluasi pelaksanaan tugas dan fungsi KPP Pratama dalam penerimaan dan pengolahan surat pemberitahuan; dan mengetahui hambatan pelaksanaan tugas dan fungsi KPP Pratama Pondok Aren dalam penerimaan dan pengolahan surat pemberitahuan. Metode yang digunakan adalah Metode Studi Kepustakaan, Metode Studi Lapangan melalui wawancara, observasi dan kuesioner. Hasilnya bahwa secara umum KPP Pratama Pondok Aren telah melaksanakan tugas dan fungsinya dalam penerimaan dan pengolahan surat pemberitahuan dengan baik. Hal ini dapat diketahui dari beberapa indikator yang disampaikan oleh Cambell sebagai bahan evaluasi pelaksanaan tugas dan fungsi KPP Pratama Pondok Aren dalam penerimaan dan pengolahan surat pemberitahuan. Salah satunya adalah efektivitas organisasi yang dapat dilihat dari NKO KPP Pratama Pondok Aren dan IKU pegawai maupun IKU KPP Pratama Pondok Aren secara keseluruhan. Penulis menggunakan target Nilai Kinerja Organisasi sebagai bahan evaluasi pelaksanaan tugas dan fungsi KPP Pratama Pondok Aren dalam penerimaan dan pengolahan surat pemberitahuan.
\end{abstract}

Kata kunci: administrasi perpajakan, administrasi publik, perpajakan, surat pemberitahuan.

\section{PENDAHULUAN}

Indonesia merupakan negara yang menempatkan pajak sebagai sumber pendapatan terbesar dalam Anggaran Pendapatan dan Belanja Negara (APBN). Pengertian pajak menurut Undang-Undang Nomor 6 Tahun 1983 tentang Ketentuan Umum dan Tata Cara Perpajakan sebagaimana telah diubah dengan Undang-Undang Nomor 16 Tahun 2009 adalah kontribusi wajib kepada negara yang terutang oleh orang pribadi atau badan yang bersifat memaksa berdasarkan undang-undang, dengan tidak mendapatkan imbalan secara langsung dan digunakan untuk keperluan negara bagi sebesar-besarnya kemakmuran rakyat.

Proporsi realisasi pendapatan perpajakan tahun 2015 sebagaimana tercantum dalam
Laporan Keuangan Pemerintah Pusat (LKPP) 2015 yang telah diaudit mencapai sekitar $82,25 \%$ dari total pendapatan negara. Pendapatan perpajakan tersebut terdiri dari pajak penghasilan ( $\mathrm{PPh}$ ) dengan proporsi 49\% dari total pendapatan perpajakan, pajak pertambahan nilai (PPN) dengan proporsi $34 \%$, cukai dengan proporsi $12 \%$, perdagangan internasional dengan proporsi 3\%, dan pajak bumi dan bangunan (PBB) dengan proporsi $2 \%$ dari total pendapatan perpajakan.

Pajak sebagai sumber pendapatan terbesar membuat pemerintah melalui Direktorat Jenderal Pajak (DJP) harus menyiapkan strategi terbaik dalam menghimpun dan mengelola pajak serta terus meningkatkan penerimaan pajak. Mulai dari perumusan aturan- 
aturan yang berkaitan dengan pajak hingga pembentukan instansi-instansi pendukung yang menghimpun pajak mulai dari level pusat hingga daerah. Berdasarkan Peraturan Menteri Keuangan Nomor 234/PMK.01/2015 tentang Organisasi dan Tata Kerja Kementerian Keuangan, Direktorat Jenderal Pajak yang berada di bawah Kementerian Keuangan memiliki tugas menyelenggarakan perumusan dan pelaksanaan kebijakan di bidang pajak sesuai dengan ketentuan peraturan perundang-undangan. Selain itu, DJP dalam melaksanakan tugasnya tersebut menyelenggarakan fungsi diantaranya adalah penyusunan norma, standar, prosedur, dan kriteria di bidang perpajakan, fungsi pelaksanaan pemantauan, evaluasi, dan pelaporan di bidang perpajakan.

Tugas dan fungsi DJP dalam pelaksanaan kebijakan di bidang perpajakan secara teknis dilaksanakan oleh kantor wilayah (Kanwil) dan kantor pelayanan pajak (KPP). Berdasarkan Peraturan Menteri Keuangan Nomor 206.2/PMK.01/2014 tentang Organisasi dan Tata Kerja Instansi Vertikal Direktorat Jenderal Pajak, Kantor Wilayah Direktorat Jenderal Pajak yang selanjutnya dalam PMK ini disebut Kantor Wilayah adalah instansi vertikal Direktorat Jenderal Pajak yang berada di bawah dan bertanggung jawab langsung kepada Direktur Jenderal Pajak. Selain itu, berdasarkan PMK tersebut DJP juga memiliki instansi vertikal lainnya yaitu kantor pelayanan pajak. Kantor Pelayanan Pajak yang selanjutnya dalam Peraturan Menteri Keuangan ini disebut KPP adalah instansi vertikal Direktorat Jenderal Pajak yang berada di bawah dan bertanggung jawab langsung kepada Kepala Kantor Wilayah. KPP terbagi menjadi 3 jenis, yaitu KPP Wajib Pajak Besar, KPP Madya, dan KPP Pratama. Sesuai dengan Pasal 54 PMK Nomor 206.2/PMK.01/2014 tentang Organisasi dan Tata Kerja Instansi Vertikal Direktorat Jenderal Pajak, KPP Wajib Pajak Besar dan KPP Madya mempunyai tugas melaksanakan penyuluhan, pelayanan, dan pengawasan Wajib Pajak di bidang Pajak Penghasilan, Pajak Pertambahan Nilai, Pajak Penjualan atas Barang Mewah, dan Pajak Tidak
Langsung Lainnya dalam wilayah wewenangnya berdasarkan peraturan perundangundangan. Sementara itu, berdasarkan Pasal 58 PMK yang sama KPP Pratama mempunyai tugas melaksanakan penyuluhan, pelayanan, dan pengawasan Wajib Pajak di bidang Pajak Penghasilan, Pajak Pertambahan Nilai, Pajak Penjualan atas Barang Mewah, Pajak Tidak Langsung Lainnya, Pajak Bumi dan Bangunan dalam wilayah wewenangnya berdasarkan peraturan perundang-undangan.

Kantor pelayanan pajak memiliki fungsi dalam mendukung pelaksanaan tugasnya. Salah satu fungsi KPP pratama yang tertuang di Pasal 59 PMK Nomor 206.2/PMK.01/2014 tentang Organisasi dan Tata Kerja Instansi Vertikal Direktorat Jenderal Pajak adalah pengadministrasian dokumen dan berkas perpajakan, penerimaan dan pengolahan surat pemberitahuan (SPT), serta penerimaan surat lainnya.

Tugas KPP dalam melaksanakan penyuluhan, pelayanan, dan pengawasan wajib pajak di bidang Pajak Penghasilan, Pajak Pertambahan Nilai, Pajak Penjualan atas Barang Mewah, Pajak Tidak Langsung Lainnya, Pajak Bumi dan Bangunan sangat berpengaruh terhadap penerimaan negara yang bersumber dari pajak, terutama dalam penerimaan $\mathrm{PPh}$ dan PPN yang menempati posisi dua teratas penyumbang terbesar pendapatan perpajakan.

Salah satu faktor yang memengaruhi keberhasilan KPP dalam menghimpun pajak diantaranya adalah kesiapan dan pelaksanaan tugas dan fungsi KPP tersebut secara optimal. Terdapat beberapa tool yang dapat digunakan untuk melihat apakah pelaksanaan tugas dan fungsi tersebut sudah optimal dilakukan. Mulai dari perencanaan yang dilakukan yang dapat dilihat melalui indikator kinerja utama KPP, pengorganisasian sumber daya manusia yang dapat dilihat melalui penempatan orang-orang yang tepat di tempat yang tepat dan pelatihan skill pegawai, pelaksanaan aturan-aturan yang berlaku, pemanfaatan sarana dan prasarana yang tersedia di KPP tersebut, serta evaluasi yang dilakukan secara berkala untuk menilai kinerja KPP dan pegawainya. 
Kesiapan KPP dalam melaksanakan tugas dan fungsinya akan berpengaruh terhadap penerimaan dan penggalian potensi pajak dalam wilayah kerjanya. Selain itu, pajak yang telah disetor dan dilapor oleh wajib pajak harus diolah dengan benar sesuai dengan ketentuan yang berlaku. Sarana untuk melaporkan pajak yang terutang tersebut adalah dengan menggunakan surat pemberitahuan (SPT). Surat pemberitahuan adalah surat yang oleh Wajib Pajak digunakan untuk melaporkan perhitungan dan/atau pembayaran pajak, objek pajak dan/atau bukan objek pajak, dan/atau harta dan kewajiban sesuai dengan ketentuan peraturan perundang-undangan perpajakan (UndangUndang Nomor 6 Tahun 1983 tentang Ketentuan Umum dan Tata Cara Perpajakan s.t.d.d Undang-Undang Nomor 16 Tahun 2009). Penerimaan dan pengolahan SPT menjadi salah satu hal yang perlu diperhatikan sebagai salah satu tolok ukur untuk menilai pelaksanaan tugas dan fungsi KPP.

Penerimaan dan pengolahan SPT menjadi hal yang penting untuk diperhatikan karena SPT merupakan alat utama yang digunakan untuk mengawasi kepatuhan wajib pajak dalam melaksanakan kewajiban perpajakannya. SPT juga dapat digunakan untuk menggali potensipotensi perpajakan. Untuk itu, harus didukung dengan kesiapan KPP sebagai organisasi yang menjalankan tugas dan fungsi tersebut. Proses penerimaan dan pengolahan SPT tersebut harus sesuai dengan aturan-aturan yang ada dan berlaku untuk menjamin kepastian hukum bagi wajib pajak.

KPP Pratama Pondok Aren sebagai KPP yang baru berdiri pada tahun 2015 yang merupakan KPP pecahan dari KPP Serpong juga harus memiliki kesiapan yang matang, karena KPP Pratama Pondok Aren memiliki wilayah kerja yang cukup luas yaitu 4 kecamatan dengan masing-masing kecamatan meliputi 6 hingga 11 kelurahan. Apalagi KPP Pratama Pondok Aren telah mampu menjadi peserta lomba KPP Percontohan 2017. KPP Pratama Pondok Aren muncul sebagai peserta lomba KPP Percontohan 2017 tentu karena memenuhi kriteria-kriteria yang telah ditentukan.
Tujuan yang ingin dicapai dalam penelitian ini adalah mengevaluasi pelaksanaan tugas dan fungsi KPP Pratama Pondok Aren dalam penerimaan dan pengolahan surat pemberitahuan dan mengetahui hambatan pelaksanaan tugas dan fungsi KPP Pratama Pondok Aren dalam penerimaan dan pengolahan surat pemberitahuan.

\section{METODE}

Penyusunan artikel ini membutuhkan datadata yang relevan dan mendukung, untuk mengumpulkan data-data tersebut penulis menggunakan dua metode pengumpulan data. Pertama, Metode Studi Kepustakaan. Metode ini merupakan metode pengumpulan data pendukung dalam penulisan karya tulis tugas akhir yang diperoleh dari buku, artikel, aturanaturan terkait yang berlaku baik cetak maupun elektronik, dan sumber-sumber lain yang relevan dengan topik yang akan dibahas. Datadata tersebut diperoleh dari materi selama masa pekuliahan maupun bersumber dari perpustakaan dan internet yang digunakan untuk memahami teori secara menyeluruh mengenai topik yang akan dibahas. Kedua, Metode Studi Lapangan. Metode ini merupakan metode pengumpulan data pendukung dalam penulisan ini yang diperoleh dengan melakukan pengamatan secara langsung proses yang terjadi di lapangan, yaitu dengan cara wawancara, observasi, dan kuesioner.

\section{HASIL DAN PEMBAHASAN \\ Evaluasi Pelaksanaan Tugas dan Fungsi}

Sesuai dengan konsep efektivitas organisasi, penulis akan mengevaluasi pelaksanaan tugas dan fungsi KPP Pratama Pondok Aren dalam penerimaan dan pengolahan SPT menggunakan beberapa indikator ukuran efektivitas organisasi menurut Cambell yang merupakan ukuran keberhasilan organisasi. Penulis hanya mengambil 4 indikator dari 12 indikator yang diungkapkan oleh Cambell. Keempat indikator tersebut adalah efektivitas keseluruhan, produktivitas, keluwesan adaptasi, dan penilaian oleh pihak luar. Keempat indikator tersebut dipilih karena faktor keter- 
sediaan data yang cukup untuk diolah dan keterkaitan dengan tema yang dibahas. Hasil pengamatan dan observasi yang penulis lakukan adalah sebagai berikut.

\section{a. Efektivitas keseluruhan}

Pendapat Cambell yang dikutip oleh Steers (1995:47) (elib.unikom.ac.id) tentang efektivitas keseluruhan adalah sejauh mana organisasi melaksanakan seluruh tugas pokoknya atau mencapai semua sasarannya. Definisi tersebut senada dengan definisi penilaian kinerja menurut Keputusan Menteri Keuangan Nomor 467/KMK.01/2014 tentang Pengelolaan Kinerja di Lingkungan Kementerian Keuangan. Penilaian kinerja menurut Keputusan Menteri Keuangan Nomor 467/KMK.01/2014 tentang Pengelolaan Kinerja di Lingkungan Kementerian Keuangan adalah penilaian terhadap kinerja organisasi dan pegawai atas realisasi kinerja dibandingkan dengan target yang ditetapkan pada periode monitoring. Output dari penilaian kinerja berupa Nilai Kinerja Organisasi (NKO), Nilai Kinerja Pegawai (NKP) dan Nilai Prestasi Kerja Pegawai (NPKP). Penulis akan menggunakan Nilai Kinerja Organisasi (NKO) sebagai alat evaluasi efektivitas secara keseluruhan pelaksanaan tugas dan fungsi KPP Pratama Pondok Aren dalam penerimaan dan pengolahan SPT.

Nilai Kinerja Organisasi yang selanjutnya disingkat NKO adalah nilai keseluruhan capaian IKU suatu organisasi dengan memperhitungkan bobot IKU dan bobot perspektif (Keputusan Menteri Keuangan Nomor 467/ KMK.01/2014 tentang Pengelolaan Kinerja di Lingkungan Kementerian Keuangan). Nilai Kinerja Organisasi merupakan output dari penilaian terhadap kinerja organisasi dan pegawai atas realisasi kinerja yang dibandingkan dengan target yang ditetapkan pada periode monitoring.

Berdasarkan data yang penulis dapatkan dari Seksi Pengolahan Data dan Informasi KPP Pratama Pondok Aren indeks capaian Nilai Kerja Organisasi KPP Pratama Pondok Aren tahun 2016 secara keseluruhan adalah 92,10\%. Hal ini menunjukkan bahwa KPP Pratama Pondok Aren mendapatkan indeks capaian yang baik dalam kinerja organisasi secara keseluruhan karena semakin dekat dengan target $100 \%$ maka kinerja organisasi tersebut semakin baik.

Penulis mengambil beberapa sasaran strategis yang terdapat pada laporan Nilai Kinerja Organisasi Kantor Pelayanan Pajak Pratama Pondok Aren yang berhubungan dengan surat pemberitahuan (SPT). Hal ini menunjukkan bahwa Kantor Pelayanan Pajak Pratama Pondok Aren berhasil mencapai target pada Indikator Kinerja Umum bahkan ada beberapa IKU yang realisasinya melampaui target yang telah ditentukan.

NKO tersebut merupakan nilai secara keseluruhan organisasi, untuk dapat mengetahui capaian yang lebih rinci mengenai pelaksanaan tugas dan fungsi KPP Pratama Pondok Aren dalam penerimaan dan pengolahan SPT penulis menggunakan IKU dari setiap seksi yang berkaitan dengan pelaksanaan tugas dan fungsi tersebut. Berikut merupakan rincian target dan capaian IKU yang berkaitan dengan pelaksanaan tugas dan fungsi KPP Pratama Pondok Aren dalam penerimaan dan pengolahan SPT.

1) Persentase penyelesaian pengadministrasian SPT Tahunan KPP Sendiri tepat waktu

Berdasarkan data yang penulis peroleh dari Subbagian Umum dan Kepatuhan Internal KPP Pratama Pondok Aren target IKU persentase penyelesaian pengadministrasian SPT Tahunan KPP sendiri tepat waktu adalah 100\% (Lampiran 21), artinya ditargetkan jumlah seluruh SPT yang seharusnya diadministrasikan dapat diadministrasikan tepat waktu. Berdasarkan hasil wawancara dengan salah seorang pegawai Subbagian Umum, Ibu Fitri, realisasi yang dicapai adalah 100\%. Hal ini menunjukkan bahwa seksi terkait telah mengadministrasikan SPT Tahunan KPP sendiri secara efektif karena realisasi sesuai dengan target. KPP sendiri dalam hal ini adalah KPP Pratama Pondok Aren.

2) Persentase pengadministrasian SPT Tahunan KPP Lain tepat waktu 
Sama halnya dengan pengadministrasian SPT Tahunan KPP sendiri, pengadministrasian SPT Tahunan KPP Lain tepat waktu juga memiliki target 100\% (Lampiran 22). Realisasi yang dapat dicapai adalah 100\%. Berdasarkan hasil wawancara dengan salah seorang pegawai Subbagian Umum, Ibu Fitri, target tersebut berhasil dicapai sepenuhnya yang berarti bahwa KPP Pratama Pondok Aren sudah efektif dalam mengadministrasikan SPT Tahunan KPP lain tepat waktu. KPP lain dalam hal ini adalah selain KPP Pratama Pondok Aren.

3) Persentase pengiriman SPT Tahunan dan SPT Masa ke Seksi PDI tepat waktu

Seksi pelayanan ditargetkan 100\% mengirim SPT Tahunan dan SPT Masa ke seksi PDI tepat waktu. Berdasarkan hasil wawancara dengan salah seorang pegawai Subbagian Umum target tersebut dapat dicapai oleh seksi pelayanan yang artinya semua SPT Tahunan dan SPT Masa yang diterima KPP Pratama Pondok Aren dikirim tepat waktu ke seksi PDI.

4) Persentase pengiriman SPT Tahunan Lebih Bayar dan SPT Masa Lebih Bayar ke seksi terkait tepat waktu

Berdasarkan data yang diperoleh dari seksi pelayanan target IKU ini adalah $100 \%$. Realisasi yang berhasil dicapai sesuai dengan keterangan yang diperoleh saat wawancara dengan salah satu pegawai Subbagian Umum, Ibu Fitri, adalah 100\%. Ibu Fitri mengatakan, "Pengiriman SPT Tahunan lebih bayar dan SPT Masa lebih bayar ke seksi terkait selalu tepat waktu, artinya target $100 \%$ itu tercapai, karena realisasinya juga $100 \%$.”

Hal ini mengindikasikan bahwa pengiriman SPT Tahunan Lebih Bayar dan SPT Masa Lebih Bayar ke seksi terkait tepat waktu sudah efektif.

5) Persentase penyelesaian perekaman SPT Tahunan tepat waktu

Berdasarkan SOP Tata Cara Penerimaan dan Pengolahan SPT Tahunan seksi yang berkaitan dengan perekaman SPT adalah seksi PDI. Perekaman SPT Tahunan tepat waktu ditargetkan tercapai 85\%. Menurut hasil wawancara dengan Ibu Fitri sebagai pegawai Subbagian Umum realisasi yang dicapai adalah 85\%. Ibu Fitri mengatakan, "IKU perekaman SPT juga tercapai sesuai target, Mbak.” Hal ini menunjukkan bahwa target tersebut dapat tercapai seluruhnya oleh seksi PDI.

6) Persentase penyelesaian perekaman SPT Masa

Sama halnya dengan perekaman SPT Tahunan, berdasarkan data IKU yang diperoleh dari Subbagian Umum KPP Pratama Pondok Aren perekaman SPT Masa juga ditargetkan 85\%. Menurut keterangan hasil wawancara dengan salah seorang pegawai Subbagian Umum, Ibu Fitri, realisasi yang dicapai adalah 85\% artinya penyelesaian perekaman SPT Masa sudah efektif. Ibu Fitri mengatakan, “Tercapai juga, Mbak. Dengan target yang 85\% itu realisasinya juga 85\%.”

7) Persentase tindak lanjut pengaduan atas permasalahan Teknologi Informasi dan Komunikasi (TIK)

IKU ini merupakan IKU dari Operator Console KPP Pratama Pondok Aren. Berdasarkan wawancara yang penulis lakukan dengan salah seorang pegawai Seksi Pengolahan Data dan Informasi atau lebih tepatnya adalah Operator Console KPP Pratama Pondok Aren, Bapak Budi, tidak ada pengaduan atas permasalahan TIK yang beliau terima. Bapak Budi mengatakan, "Wah ! Saya belum pernah dapet aduan ada masalah TIK, Mbak. Soalnya kan KPP Pratama Pondok Aren kan KPP yang baru berdiri, jadi seluruh sarana dan prasarana yang ada dalam kondisi baik.” Berdasarkan keterangan yang dituturkan oleh Bapak Budi, kriteria sarana dan prasarana dalam kondisi baik adalah apabila saat menggunakan sarana dan prasarana tersebut tidak terdapat kendala yang dapat menghambat tugas dan fungsi yang sedang dilaksanakan. Bapak Budi mengatakan, "Sarana dan prasarana termasuk baik ya kalau tidak ada keluhan atau masalah waktu kita pakai itu 
untuk bertugas.” Target yang ditetapkan untuk IKU ini adalah 100\%. Realisasi yang dicapai atas IKU ini juga 100\% karena tidak ada sama sekali keluhan yang diterima. Jadi, target IKU ini tercapai.

8) Persentase pegawai yang memenuhi jamlat IKU ini merupakan IKU Subbagian Umum dan Kepatuhan Internal. IKU ini memiliki sasaran strategis SDM yang kompetitif (Lampiran 28). SDM merupakan salah satu faktor yang sangat berpengaruh terhadap keberhasilan organisasi melaksanakan tugas dan fungsinya untuk mencapai target yang telah ditentukan. Setiap pegawai di KPP Pratama Pondok Aren memiliki standar jam latihan yang telah ditentukan.

Setiap seksi memiliki standar jam latihan berbeda-beda serta pencapaian atas standar jam latihan yang telah ditentukan pun berbeda-beda. Ada seksi yang seluruh pegawainya telah memenuhi standar jam latihan, namun ada juga yang belum seluruhnya memenuhi standar jam latihan yang telah ditentukan. Seksi-seksi yang pegawainya telah memenuhi jamlat $100 \%$ adalah Seksi Waskon II berjumlah 9 orang, Seksi Waskon III berjumlah 7 orang, Seksi Waskon IV berjumlah 7 orang, dan Subbagian Umum dan Kepatuhan Internal berjumlah 10 orang. Seksi yang paling sedikit memenuhi standar jam latihan adalah fungsional yaitu hanya 2 orang yang memenuhi standar jam latihan dari 11 orang fungsional atau sekitar 18,18\%.

Berdasarkan data yang penulis peroleh dari Subbagian Umum dan Kepatuhan Internal bahwa IKU ini memiliki target sebesar $55 \%$. Berdasarkan data yang penulis peroleh dari Seksi PDI bahwa KPP Pratama Pondok Aren mencapai realisasi 66,67\% atas IKU ini. Hal ini menunjukkan bahwa sebagian besar pegawai di KPP Pratama Pondok Aren telah memenuhi standar jam latihan dan memiliki keseriusan untuk terus meningkatkan kemampuan dan menjadi SDM yang kompetitif.

9) Persentase bimbingan dan konsultasi terhadap bawahan langsung
IKU ini merupakan IKU Subbagian Umum dan Kepatuhan Internal. Berdasarkan hasil wawancara dengan Kepala Subbagian Umum dan Kepatuhan Internal KPP Pratama Pondok Aren, bimbingan dan konsultasi dilakukan secara fleksibel dan tidak ada waktu khusus. Jika ada pegawainya yang meminta saran, konsultasi, dan sebagainya maka saat itu juga dilakukan bimbingan terhadap pegawai tersebut. Bimbingan juga dilakukan jika Kepala Subbagian Umum dan Kepatuhan Internal (SUKI) merasa harus membimbing pegawainya baik secara langsung maupun tidak langsung saat mengerjakan tugas tertentu. Misalnya jika Kepala SUKI melihat pegawainya tidak mengerti terhadap tugas yang harus dikerjakan, Beliau langsung memberikan arahan terhadap pegawai tersebut. Penulis tidak mendapatkan angka realisasi IKU ini baik dari Seksi PDI maupun SUKI.

10)Persentase realisasi tindak lanjut SPT Tahunan tidak lengkap tepat waktu IKU ini merupakan IKU dari Seksi Pengawasan Konsultasi I. Berdasarkan data yang diperoleh dari Subbagian Umum dan Kepatuhan Internal target IKU ini adalah 100\%. Berdasarkan wawancara yang penulis lakukan dengan salah seorang pegawai Subbagian Umum dan Kepatuhan Internal, Ibu Fitri, capaian IKU ini adalah 100\%. Artinya bahwa seluruh SPT yang tidak lengkap telah selesai ditindaklanjuti oleh AR Seksi Waskon I pada jangka waktu yang telah ditetapkan. Target IKU ini berhasil tercapai.

\section{b. Produktivitas}

Kuantitas atau volume produk yang akan penulis gunakan untuk mengukur efektivitas KPP Pratama Pondok Aren dalam penerimaan dan pengolahan SPT adalah jumlah realisasi penerimaan pajak tahun 2016. Hal ini dikarenakan penerimaan dan pengolahan SPT berujung pada penghimpunan dan penggalian potensi pajak.

Berdasarkan data yang penulis peroleh dari Seksi PDI KPP Pratama Pondok Aren 
realisasi penerimaan pajak tahun 2016 adalah sebesar Rp2.334.909.825.383,00. Angka tersebut merupakan realisasi 78,76\% dari target penerimaan pajak KPP Pratama Pondok Aren tahun 2016. Pencapaian tahun 2016 mengalami pertumbuhan sebesar 12,95\% dari tahun sebelumnya. Hal ini menunjukkan bahwa KPP Pratama Pondok Aren cukup efektif dalam menjalankan tugas dan fungsinya khususnya dalam penerimaan dan pengolahan SPT karena pajak yang berhasil dihimpun mencapai $78,76 \%$ dari target dan mengalami pertumbuhan dari tahun sebelumnya mencapai 12,95\%.

\section{c. Keluwesan adaptasi}

Tata cara penerimaan dan pengolahan surat pemberitahuan diatur dalam Keputusan Menteri Keuangan Nomor 82/KMK.03/2003 tentang Perubahan atas Keputusan Menteri Keuangan Nomor 536/KMK.04/2000 tentang Tata Cara Penerimaan dan Pengolahan Surat Pemberitahuan. Di dalam KMK tersebut disebutkan bahwa pengolahan Surat Pemberitahuan adalah serangkaian kegiatan yang dilakukan meliputi penilaian dan perekaman Surat Pemberitahuan. Penilaian Surat Pemberitahuan adalah serangkaian kegiatan yang dilakukan untuk menilai kelengkapan pengisian Surat Pemberitahuan dan lampiran-lampirannya. Sedangkan Perekaman Surat Pemberitahuan adalah serangkaian kegiatan yang dilakukan untuk memasukan semua elemen surat pemberitahuan ke dalam Sistem Informasi Perpajakan.

Lebih rinci aturan mengenai tata cara penerimaan dan pengolahan SPT diatur dalam Peraturan Direktur Jenderal Pajak Nomor PER - 01/PJ/2016 tentang Tata Cara Penerimaan dan Pengolahan Surat Pemberitahuan Tahunan, Peraturan Direktur Jenderal Pajak Nomor PER-21/PJ/2013 tentang Perubahan atas Peraturan Direktur Jenderal Pajak Nomor PER-2/PJ/2011 tentang Tata Cara Penerimaan dan Pengolahan Surat Pemberitahuan Masa Pajak Pertambahan Nilai (SPT Masa PPN), dan Keputusan Direktur Jenderal Pajak Nomor KEP-2017/PJ/2001 tentang Kewajiban Menyampaikan Surat Pemberitahuan Masa Pajak Penghasilan Pasal 25 untuk Wajib Pajak Orang
Pribadi. Aturan lebih rinci lagi mengenai tata cara penerimaan dan pengolahan SPT terdapat pada SOP di KPP masing-masing. SOP yang bisa digunakan adalah SOP Tata Cara Penerimaan dan Pengolahan SPT Tahunan, SOP Tata Cara Penerimaan dan Pengolahan SPT Masa PPh, dan SOP Tata Cara Penerimaan dan Pengolahan SPT Masa PPN.

Tata cara penerimaan dan pengolahan SPT di KPP Pratama Pondok Aren seharusnya mengikuti aturan-aturan tersebut khususnya SOP terkait. Berdasarkan hasil wawancara dengan beberapa petugas di Tempat Pelayanan Terpadu (TPT) kondisi riil di lapangan tidak sepenuhnya menerapkan apa yang ada di SOP, ada perbedaan antara SOP dan penerapannya di lapangan. Hal ini disebabkan karena SOP yang ada sudah tidak lagi relevan dengan kondisi nyata di lapangan. SOP Tata Cara Penerimaan dan Pengolahan SPT Tahunan diterbitkan tahun 2008 dan belum ada perubahan lagi, SOP Tata Cara Penerimaan dan Pengolahan SPT Masa PPh terbit tahun 2014, dan SOP Tata Cara Penerimaan dan Pengolahan SPT Masa PPN terbit tahun 2014. Salah satu contoh ketidaksesuaian antara SOP dan keandaan riil di lapangan adalah SOP belum mengatur tentang cara penerimaan SPT elektronik melalui aplikasi $e$-filling. Hal ini membuat pihak KPP harus membuat kebijakan yang fleksibel mengikuti perkembangan yang ada. Petugas TPT mengaku hanya mengikuti arahan dari atasan untuk melakukan tugas-tugas yang belum diatur, aturannya belum diganti, atau aturan yang tidak dipahami.

SOP Tata Cara Penerimaan dan Pengolahan SPT Tahunan, SOP Tata Cara Penerimaan dan Pengolahan SPT Masa PPN, dan SOP Tata Cara Penerimaan dan Pengolahan SPT Masa PPh dapat dilihat di lampiran 15, 16 , dan 17. Tata cara penerimaan dan pengolahan SPT yang penulis dapatkan dari hasil wawancara kepada salah satu petugas TPT di KPP Pratama Pondok Aren, Bapak Resky, sama dengan yang tertulis di SOP jika SPT tersebut diterima melalui petugas TPT. Namun dalam hal penerimaan SPT melalui aplikasi $e$-filling, penulis tidak dapat memban- 
dingkannya dengan SOP karena belum ada SOP yang mengatur tentang hal tersebut.

\section{d. Penilaian oleh pihak luar}

Pelaksanaan tugas dan fungsi KPP Pratama Pondok Aren dalam penerimaan dan pengolahan SPT dimulai dari tugas dan fungsi pelayanan yaitu saat melakukan penerimaan SPT dari wajib pajak. Penilaian oleh pihak luar yaitu penilaian mengenai organisasi atau unit organisasi oleh mereka (individu atau organisasi) dalam lingkungannya, yaitu pihakpihak dengan siapa organisasi ini berhubungan. Pihak luar dalam hal ini adalah wajib pajak.

Pengamatan dilakukan untuk mengetahui apakah standar pelayanan telah dipenuhi oleh KPP Pratama Pondok Aren. Penulis membandingkan antara Peraturan Direktur Jenderal Pajak Nomor PER-02/PJ/2017 tentang Perubahan atas Peraturan Direktur Jenderal Pajak Nomor PER-27/PJ/2016 tentang Standar Pelayanan di Tempat Pelayanan Terpadu Kantor Pelayanan Pajak dan kondsi riil di lapangan. Penulis mengambil konsentrasi evaluasi pelayanan di TPT karena pelaksanaan tugas dan fungsi pelayanan KPP Pratama Pondok Aren dalam penerimaan dan pengolahan SPT hanya dapat dilihat di TPT saat WP melaporkan SPT-nya kepada petugas TPT.

\section{Hambatan Pelaksanaan Tugas dan Fungsi}

Setelah melakukan pengamatan kegiatan penerimaan SPT di TPT dan melakukan wawancara dengan beberapa wajib pajak dan beberapa pegawai di KPP Pratama Pondok Aren yaitu pelaksana Seksi Pelayanan, pelaksana dan kepala Subbagian Umum, dan pelaksana Seksi Pengolahan Data dan Informasi, penulis mengetahui terdapat beberapa hambatan yang dihadapi KPP Pratama Pondok Aren selama melaksanakan tugas dan fungsinya dalam penerimaan dan pengolahan SPT. Beberapa hambatan tersebut adalah sebagai berikut:

a. Hambatan terkait sarana dan prasarana

Belum adanya fasilitas untuk para penyandang cacat, tempat parkir yang belum bisa menampung semua kendaraan saat pengunjung ramai sehingga pengunjung diarahkan untuk memarkirkan kendaraannya di tempat parkir kampus PKN STAN atau di sekitar kolam PKN STAN. Hal tersebut sedikit mengganggu jalan dan mengganggu pemandangan karena banyaknya kendaraan yang diparkir bukan di tempat yang seharusnya. Lokasi gedung KPP Pratama Pondok Aren yang berada di dalam area kampus PKN STAN menyebabkan agak sulit ditemui oleh WP yang baru pertama kali datang ke KPP Pratama Pondok Aren sehingga mereka harus sering bertanya pada mahasiswa atau warga kampus lainnya di mana letak gedung KPP Pratama Pondok Aren. Salah satu wajib pajak yang datang ke KPP Pratama Pondok Aren, Ibu Maulida mengatakan, “Tadi saya masuknya dari kampus tuh Mbak, yang tempat parkir itu, terus saya bingung kemana jalannya. Saya nanya aja sama orang yang lagi jalan, mahasiswa kayaknya. Terus saya dikasih tunjuk arahnya kemana.” Selain itu, wajib pajak yang lain juga menuturkan keluhannya. Pak Arif mengatakan, "Ini saya bukan pertama kali kesini Mbak, sebelumnya saya pernah juga. Waktu lagi rame-ramenya di KPP. Saya markir mobilnya deket kolam itu Mbak, yang ada tulisan STAN."

\section{b. Hambatan terkait sambungan internet}

Hambatan sambungan internet merupakan hambatan yang tidak dapat diprediksi kapan bisa terjadi dan berapa lama terjadi. Terkadang sambungan internet di KPP Pratama Pondok Aren mengalami gangguan sehingga beberapa proses terhambat bahkan tidak dapat dilakukan sama sekali jika internet mengalami gangguan. Apabila sambungan internet mengalami gangguan maka aplikasi-aplikasi yang dibutuhkan dalam proses penerimaan dan pengolahan SPT tidak dapat dibuka sehingga pelaksanaan menjadi terhambat.

\section{c. Hambatan terkait SDM}

Jumlah SDM di KPP Pratama Pondok Aren khususnya di bagian pelayanan kurang jika dibandingkan dengan jumlah WP yang terdaftar di KPP Pratama PondokAren. Apalagi saat jumlah pengunjung lebih banyak dari hari biasanya, yaitu saat jatuh tempo pelaporan SPT, petugas bagian pelayanan akan melayani jauh 
lebih banyak WP dibandingkan hari-hari biasanya. Kurangnya jumlah petugas di bagian pelayanan menyebabkan antrean panjang dan proses selanjutnya menjadi sedikit terhambat. WP pun terkadang merasa bosan apabila menunggu terlalu lama.

\section{SIMPULAN}

Evaluasi pelaksanaan tugas dan fungsi KPP Pratama Pondok Aren dalam penerimaan dan pengolahan surat pemberitahuan tidak terlepas dari keikutsertaan wajib pajak dalam pelaksanaannya. Wajib pajak sebagai pihak yang menerima manfaat atau pengguna jasa pelayanan publik dapat dijadikan indikator keberhasilan KPP Pratama Pondok Aren melaksanakan tugas dan fungsinya dalam penerimaan dan pengolahan SPT. Berdasarkan hasil wawancara dengan beberapa wajib pajak yang datang ke TPT KPP Pratama Pondok Aren dan pengisian kuesioner penilaian oleh wajib pajak terhadap pelayanan yang diberikan KPP Pratama Pondok Aren menunjukan bahwa wajib pajak merasa puas atas pelayanan yang diberikan oleh KPP Pratama Pondok Aren. KPP Pratama Pondok Aren dinilai sangat baik atas pelayanan yang diberikan kepada wajib pajak. Pelayanan di TPT KPP Pratama Pondok Aren telah sesuai dengan Peraturan Direktur Jenderal Pajak Nomor PER-02/PJ/2017 tentang Perubahan atas Peraturan Direktur Jenderal Pajak Nomor PER-27/PJ/2016 tentang Standar Pelayanan di Tempat Pelayanan Terpadu Kantor Pelayanan Pajak. Hal ini menunjukkan bahwa KPP Pratama Pondok Aren telah melaksanakan tugas dan fungsinya dalam penerimaan dan pengolahan SPT dengan baik khususnya dalam memberikan pelayanan kepada wajib pajak yang datang ke TPT KPP Pratama Pondok Aren.

Masih terdapat beberapa hambatan yang ditemui di KPP Pratama Pondok Aren dalam melaksanakan tugas dan fungsinya dalam penerimaan dan pengolahan SPT. Hambatanhambatan tersebut adalah belum lengkapnya fasilitas serta sarana dan prasarana di KPP Pratama Pondok Aren. Namun semua sarana dan prasarana yang telah tersedia di KPP
Pratama Pondok Aren masih dalam kondisi baik hal ini dikarenakan KPP Pratama Pondok Aren merupakan KPP yang baru berdiri di tahun 2015. Gangguan sambungan internet juga dapat menghambat proses pelaksanaan tugas yang sedang dilakukan. Jumlah SDM yang kurang khususnya di bagian pelayanan saat hari-hari tertentu dapat menghambat pelaksanaan tugas dan fungsi KPP Pratama Pondok Aren dalam penerimaan dan pengolahan surat pemberitahuan.

\section{DAFTAR RUJUKAN}

Keputusan Menteri Keuangan Nomor 82/ KMK.03/2003 tentang Perubahan atas Keputusan Menteri Keuangan Nomor 536/KMK.04/2000 Tentang Tata Cara Penerimaan dan Pengolahan Surat Pemberitahuan

Keputusan Menteri Keuangan Nomor 467 Tahun 2014 tentang Pengelolaan Kinerja di Lingkungan Kementerian Keuangan Keputusan Direktur Jenderal Pajak Nomor KEP-207/PJ/2001 tentang Kewajiban Menyampaikan Surat Pemberitahuan Masa Pajak Penghasilan Pasal 25 Untuk Wajib Pajak Orang Pribadi

Lubis, Satria Hadi. 2011. Etika Profesi PNS. Tangerang Selatan: STAN.

Peraturan Menteri Keuangan Nomor 206.2/ PMK.01/2014 tentang Organisasi dan Tata Kerja Instansi Vertikal Direktorat Jenderal Pajak

Peraturan Menteri Keuangan Nomor 243/ PMK.03/2014 tentang Surat Pemberitahuan (SPT)

Peraturan Menteri Keuangan Nomor 234/ PMK.01/2015 tentang Organisasi dan Tata Kerja Kementerian Keuangan

Peraturan Menteri Keuangan Nomor 131/ PMK.01/2015tentang Pedoman Penyusunan Proses Bisnis, Kerangka Pengambilan Keputusan, dan Standar Operasional Prosedur di Lingkungan Kementerian Keuangan Standar Operasional Prosedur Peraturan Direktur Jenderal Pajak Nomor PER-21/PJ/2013 tentang Perubahan atas Peraturan Direktur Jendera Pajak 
88 Jurnal Kebijakan Publik, Volume 9, Nomor 2, Oktober 2018, hlm. 61-124

Nomor PER-2/PJ/2011 tentang Tata Cara Penerimaan dan Pengolahan Surat Pemberitahuan Masa Pajak Pertambahan Nilai (SPT Masa PPN)

Peraturan Direktur Jenderal Pajak Nomor PER - 01/PJ/2016 tentang Tata Cara Penerimaan dan Pengolahan Surat Pemberitahuan Tahunan

Peraturan Direktur Jenderal Pajak Nomor PER-02/PJ/2017 tentang Perubahan atas Peraturan Direktur Jenderal Pajak Nomor PER-27/PJ/2016 tentang Standar Pelayanan di Tempat Pelayanan Terpadu Kantor Pelayanan Pajak
Peraturan Direktur Jenderal Pajak Nomor PER-02/PJ/2017 tentang Perubahan atas Peraturan Direktur Jenderal Pajak Nomor PER-27/PJ/2016 tentang Standar Pelayanan di Tempat Pelayanan Terpadu Kantor Pelayanan Pajak

Undang-Undang Nomor 6 Tahun 1983 tentang Ketentuan Umum dan Tata Cara Perpajakan sebagaimana telah diubah dengan Undang-Undang Nomor 16 Tahun 2009

Undang-Undang Nomor 25 Tahun 2009 tentang Pelayanan Publik. 